Filosofia Theoretica: Journal of African Philosophy, Culture and Religions 


\title{
APPIAH ON RACE AND IDENTITY IN THE ILLUSIONS OF RACE: A REJOINDER
}

DOI: http://dx.doi.org/10.4314/ft.v4i2.2

\author{
David A. OYEDOLA
}

Department of Philosophy, Obafemi Awolowo University,Ile-Ife, Nigeria

\begin{abstract}
Whether Appiah's concession in [The Illusions of Race, 1992] that there are no races can stand vis-a-vis Masolo's submission in "African Philosophy and the Postcolonial: some Misleading Abstractions about Identity" (1997) that identity is impossible, it is worthy to note that much of what is entailed in human societies tend toward the exaltation and protection of self-interest. Self-interest, as it is related to particular or individual entities, to a great extent, presupposes the ontology of different races and identities. Paul Taylor in "Appiah's Uncompleted Argument: W.E.B. Du Bois and the Reality of Race," to begin with, asserts that races and identity struggles are real entities as individuals': where this can be said to aid and abet racial differences. Though, there are those who lend credence to Appiah's and Masolo's explications like Hountondji and Gyekye; however, it is noteworthy that philosophers like Du Bois, Nkrumah, Fanon, Mandela, Senghor, Hallen and Cabral who, in one way or the other, lend credence to Taylor's claim, could not have said so without taking into consideration, the colonial and anthropological experiences which has, in one way or the other, has affected Africa and Africans. Despite the latter, certain flaws like (i) the failure to acknowledge the utility and global importance of human race or family, and (ii) the failure to recognize the distinctiveness of each existing race, tribe or ethnicities in a diverse political, religious, and culture-biased world, are inherent in Taylor's, Appiah's and Masolo's views coupled with those who lend credence to their views. In this study, nevertheless, it is conceded that it is not enough, as a derivative of Appiah's skepticism about race and identity, to gesture at racial and identity concerns while using logical incoherence, globality, methodological separatism and cosmopolitan traits to undermine the relevance of identity which is the soul of the postcolonial quest for a distinct African race or black (African) philosophy.
\end{abstract}

Keywords: Race, Identity, Black/African Philosophy, Global Politics, Morality

\section{Introduction}

Where there are different but conflicting ideas, choosing one as superior to another seem preposterous. Just as this difficulty cannot be ignored, any of the following thesis cannot be placed over and above the other: Kwame Appiah's assertion that "there are no races" $(1992,45)$, D.A. Masolo's position that identity is impossible $(1997,288)$, Du Bois's concession that "in our calmer moments we 
must acknowledge that human beings are divided into races: for, each race has a distinct message to preach or give to the world" (1998, 269-271), Paul Taylor's view that "races are real entities as individuals" (2000, 104), Moses Makinde's explication that "there exist, the idea of African philosophy" (2010, 3), and Barry Hallen's opinion that "there are elements to African cognition that are sufficiently unique or distinctive to set African discourse apart from any other" $(2002,35)$. To assert that any of these claims is superior to other views about the existence or non-existence of race, identity or black (African) philosophy is to give a clear representation of the difficulty which the contemporary idea of a common or distinctive notion of human race will have to resolve. The nature of this resolution lies in the currency and correctness of the outright denial of race and identity given Appiah and Masolo's extreme views. But we need to know how far Appiah's and Masolo's extreme views can go in resolving the differences in identities, races, individual beliefs, and difference in opinions. The rational basis for Appiah's and Masolo's extremism, according to certain philosophers like Nkrumah, Nyerere, Cabral, Fanon, Soyinka, Senghor, Tempels, Makinde, Mandela, Oke, Horton, Hallen, Oladipo, and Olela is meant to resolve the lingering crisis of racial subjugation and post-colonial struggle which the ideas of a distinct race and identity may have caused. To continue in the search for a distinct post-colonial race and identity as Appiah and Masolo believes, however, is to continue in the superiority-inferiority analysis of race which is of no importance given what human family will help humanity to achieve. Nonetheless, it is somewhat obvious that the problem which the views that there are no races and identity have caused to different belief-systems is greater than what it helps to resolve. Emevwo Biakolo in "Categories of Cross-Cultural Cognition and the African Condition" (1998, 1-14) and Ehiedu E.G. Iweriebor's "The Psychology of Colonialism" (2002, 465-482) are classic examples, in this case. The reason is simple: the crises which are on-going between different races and identities have gone beyond Appiah's and Masolo's academic exercise. The idea that there are different races and identities live in the actions and thought of people. It directs the actions and lives of men. Thus, it is difficult to deny the effects of colonialism in/on Africa. Also, it is a possibility to notice the impacts of neo-colonialism in the affairs of many African states; it may be impossible to deny the economic, social, political, and cultural dependence of Africa on Europe and America, which is named globalisation. Even when we seem to see a clear reason for accepting Appiah's and Masolo's explications, we seem not to bother ourselves because we cannot ignore the agitations and killings of the Al-Qaeda terrorist group in the Middle-East. Their reason for engaging in this terrorist activity is a derivative of the political and religious marginalization in the hands of the Western elite countries like the United States, Britain, France, etc. Similarly, the perpetual/consistent dependence of the African continent on the West and the various killings happening in our world because of the ways in which the West/United States meddles with the affairs of other countries cannot be ignored. 
All these are clear pointers to the fact that there are identities and races which we must recognize to know how to tackle whatever evil the entire world or some parts of the world should be ready to face, possibly resolve them.

Our main objective will be to understand, as deeply as we can, the nature of the controversy created, on the one hand, by Appiah and Masolo, and on the other hand, Nkrumah, Gyekye, Wiredu, Kaphagawani, Senghor, Cabral, Fanon, Makinde, Ibout Emmanuel, Wiredu, Oruka, Soyinka, Achebe, Oke, Mandela and other social deconstructionists that races exist and that the search for post-colonial identity is still on-going in Africa and other parts of the world where people feel marginalized religiously, politically, socially, mentally, economically, etc.

This study affirms that Appiah's claim have dire consequences on the search for distinct identity for different but not opposing races. In this light, a comparative analysis of Appiah's claim will be carried out in view of his recent works like [Color Conscious: The Political Morality of Race, 1996], [The Ethics of Identity, 2005], [Cosmopolitanism: Ethics in a World of Strangers, 2006], alongside D.A. Masolo's view in "African Philosophy and the Postcolonial: Some Misleading Abstractions about Identity" (1997), vis-à-vis some other opposing reviews done by W.E.B. Du Bois' explication in "The Conservation of Races" (1998), Barry Hallen in [A Short History of African Philosophy, 2002], Lucius Outlaw in "African, African American, Africana Philosophy," Tsenay Serequeberhan's "Philosophy and Post-Colonial African," Paul Taylor's "Appiah's Uncompleted Argument: W.E.B. Du Bois and the Reality of Race," Kwasi Wiredu in "How Not to Compare African Thought with Western Thought," and so on. Appiah's comment in [The Illusions of Race] $(1992,32)$ will be a good orienting device for this study. Before Appiah's comment is elucidated, the quest for the genesis and impact of race theory will be discussed.

\section{The Quest to Understand the Impact of 'Race' Theory}

Whether as a concept or a theory, the idea of race has been subjected to sceptical and analytical review by philosophers, scholars and commentators. In the contemporary epoch, it has been reviewed using analyticity, a tool used in philosophy to juggle on both sides of an issue. This can be seen in the light of the environmental and socio-political ordering/view, given the way in which subject/object analysis or relations has succeeded in re-shaping our thought and orientation. Since the philosophical and socio-political analysis helps in using the second-order (critical) tool to discuss issues; hence, the understanding of the nitty-gritty of subjects like race and identity cannot be ignored. Precisely, varying assessment has been carried out on race and identity, from the analytic, political, theoretical and conceptual points of view. For instance, Leopold Senghor, in "Negritude and African Socialism," posits that "reason is deemed Hellenic and emotion is African" (1998, 438-448), while Aime Cesaire in "Discourse on Colonialism" sought to recognize the collective colonial experience of Blacks (1998, 222-227). Both saw Negritude, Socialism and Colonialism as the fact of 
being black which defines the identity of blacks. By implication, the African recognition of blackness may be considered homogeny because it reiterates the need to recognize the physiological attributes of Africans as distinct from others (non-Africans). But on the other hand, the attempt to translate humanity to mean human race or one race is, in a way, difficult to accept. If care is not taken, Senghor and Cesaire may be used as straw men; they may be taken serious on the relevance of race and identity to global political discourse. The implication is that if races are globalized or reduced to an entity, the term Negritude which is derived from "Negre" (meaning negro-ness or blackness) would imply that Negre is an attempt to differentiate individuals in the individual-writ large or global community. This should be deemed unfriendly. There are always more than one or more senses to which race can be conceived, perceived, reviewed or narrated.

In this respect, J. Tara's and K. Pyke's view that "what is most arresting about critical race theory is that...it turns its back on the Western tradition of rational inquiry, forswearing analysis for narrative" (TARA 2005, 70-71; PYKE 2010, 552), could possibly represent what the logical arguments and empirical data of the critical race theorists like Hume, Hegel and some 20th century American illusionists, says of race and identity that they are fictional, sciencefictional, quasi-fictional, autobiographical, and anecdotal - designed to expose the pervasive and deliberating racism of America today; but by repudiating reasoned argumentation, "the storytellers (i.e., United States, Great Britain, etc) reinforce stereotypes about the intellectual capacities of nonwhites" (PYKE 2010, 553). However, what many African social and political philosophers like Senghor, Nyerere, Cesaire, Nkrumah, Sékou Touré, Mandela, Cabral, and Wiredu have maintained is filled with charges that academia (from the Euro-American point of view) has been racist and dismissive of the African perspective about what race and identity should constitute.. The relationship between the above claim and what this paper posit is that, Tara's and Pyke's claim is not a response to the earlier erroneous claims about race that race and identity are not ontological, as asserted by Appiah in [Color Conscious: The Political Morality of Race, 1996].

Going by the relations between the knowing subjects (whites in America) and the objects (non-whites; blacks) in any account of the epistemological or anthropological process, Emevwo Biakolo says that, the determining factor here was race $(1998,1)$. As Biakolo says, the ideology behind the building of the superior-inferior paradigm in racial discourse is not in doubt because it is constant with the revealing of an ingenuity which goes further to confirm the political project behind the Western/American construction of cultural paradigm of the "Other"- Africans or blacks $(1998,1)$. This political project, in Biakolo's words can be used to establish the following categorization: whites are seen as civilized, logical, conceptual, have written history or literature, and that, they are scientific; while blacks, Africans or "others" are seen as follows: savages, prelogical, perceptual, religious, and they have oral or non-literature history $(1998,2-11)$. 
The critical race theory, using the academic discipline, is often associated with many of the controversial issues involved in the pursuit of equality issues related to race and ethnicity. Firstly, it is used in critiquing white superiority; this is because the white supremacy and racial power are maintained over time and in particular; if the law is allowed to play a role in the process of equality, white domination would be a forgone issue. Put differently, the critical race theory helps in investigating the possibility of pursuing a project of achieving racial emancipation and anti-subordination. In another dimension, critical race theory recognizes that racism is engrained in the fabric and system of the American society. Critical race theory talks about the roles that colonialism has played in the lives of the Africans. It highlights what neo-colonialism is currently playing in the lives of many African nations. Critical race theory identifies that the power structures that instituted racism and racial subjugations are based on white privilege and white supremacy which perpetuates the marginalization of people of color, blacks on the African continent, rejects oral traditions and first-order cultures and brought capitalism to Africa instead of promoting communal living (Nyerere's Ujamaa - meaning brotherhood or extended family).

In the creation of a common or unified village - provided that Nyerere's explication, in his work "Ujamaa: The Basis for African Socialism," where Globality or globalization is said to be confusing to Africa, and such global village seems to have confused most Africans. If this is so, then, Appiah, Masolo and their kinds (in Hountondji, Gyekye, Olúfémi Taiwo, etc) may have been disillusioned into thinking that since the hybridization of Africanness (a form of identity; racial in nature) has failed to benefit Africa - why still continue talking about post-colonial identity? Blacks have long fought on so many fronts colonialism happened in Africa just as we cannot deny the effects that the Holocaust had on the Jews and 'others' who were deemed as mixed bloods or original sinners. It is undeniably true that Africa experienced colonial rule. During the colonial period, it becomes noticeable that Euro-African relations changed, despite the long-established relations based on trade. Europe conquered Africa and used its people as labour to produce materials for export. Colonialism, therefore, left the mental culture of the Africans in ruins. Precisely, Africa was left with physical culture like the practice and beliefs in gods, folklores, dances, etc, but the mental development and stamp of acceptance was held by the Europeans and Americans, which till date, still make Africa and Africans to look up to the West for recognition, acceptance, to rubber stamp any work done in Africa and by Africans, etc. It is noteworthy that just as nationalism intensified in Africa, colonialism crumbled. In its crumbling, the effects of colonial rule failed to prepare many African leaders for the future. Hence, African nations were given freedom to conduct and govern their respective nations, but these (African) leaders did not know that (i) their respective nations and Africa, as a whole, was not given political, economic and educational freedom/independence; (ii) the ground prepared by the Europeans was ill and shaky; and (ii) there would, as a 
matter of necessity, be the post-colonial need for the re-subjectivisation of Africa. However, this should not sufficiently become the basis for the contemporary underdevelopment of Africa. To reinvent oneself irrespective of racial and cultural differences, mean a lot to human race.

What is the reason behind Appiah's position that races do not exist (his ground: "there is nothing in the world that can do all we ask race to do for us" $(1992,45))$ given (i) the hybridisation of African identity and Africanism and (ii) the post-colonial need for re-subjectivisation? Even if Africa is stripped of the differentiating ability, and the unification of all human physiology is established, would Africa have embraced Appiah's description of human race, cosmopolitanism, common identity, and racial sameness (homogenism)? What could have influenced Appiah into making his conclusion that there are no races?

Appiah's aim in [The Illusions of Race] is to address the notions of race and identity as explicated by Du Bois $(1992,28)$. In taking a look at these notions, he ushers these notions into the light mainly to make visible what appear to him to be imperfections. He (Appiah) took the notions of race and identity beyond $\mathrm{Du}$ Bois. There are two different viewpoints on the notion of race which Appiah and $\mathrm{Du}$ Bois expresses; the latter advances the importance, significance and divisiveness of races, the former attempts to create wholesale skepticism thereby reducing the relevance of race by asserting that there are no races (APPIAH 1992, 45). Appiah turns out to be a racial sceptic; biological race does not exist, he says; if races do exist, it is to be metaphysically indefensible and to be morally dangerous; as a result, to eliminate "race" from our metaphysical vocabularies is an important step toward the right, or a rational and just-world-view. But Du Bois, as Appiah explicates, is a racialist. Races, for Du Bois, are real entities: racial identities are real and valuable properties of human individuals; and where racial solidarity can help realize such human goods as equality and selfactualisation.

Appiah's starting point of Du Bois's discourse on race is that the problem for the Negro is the discovery and expression of the message of his or her race (1992, 29). Du Bois's view on the individualistic form of identity and race influences the diverse responses to the problem of the person of different races and identities. As a result of Du Bois's claim, Appiah's sceptical tendency enlists him as a race and identity eliminativist. Race is considered as a dangerous factor for human life and development.

Yet this is no final curtain. Appiah revisited the notion of race and identity in his later works like [Color Conscious: The Political Morality of Race, 1996], [The Ethics of Identity, 2005] and [Cosmopolitanism: Ethics in a World of Strangers, 2006]. Admittedly, the concepts of race and identity are the unluckiest of the notions in all: the archetypal arch-pragmatist, fundamentally opposed to the idea of contextual or continental notions of race and identity. Though, Appiah may not be perceived, necessarily, as the sworn enemy of race and identity; but for a man who was born as an African during the post-colonial search for a distinct African 
identity, it has always been clear that the implicit belief that the non-existence of specific race and identity stirs something particularly deep inside him.

\section{Appiah: Du Bois as a 'Socio-historical Racialist'}

Du Bois' view, in "The Conservation of Races," as Appiah explicates in [The Illusion of Races], underscore the essential differences in races and the relevance thereof to the notions of racism and identity in our world. The differences in races as situated in Appiah's discussion of $\mathrm{Du}$ Bois is premised on Du Bois's understanding of the long period of European control of Africa and the neglect shown to the 'person' of Negroes in the United States. A person has social, intellectual, psychological, cultural, physiological, emotional, spiritual and legal aspects. Du Bois's understanding suggests that the 'personhood' of the Negroes has been impaired, where the holistic approach to personhood is the lack of impairment. As Appiah noted, Du Bois's discussion of the natural cleavage shows that there is a division of human beings into three great families - the whites, the Negroes and the yellow race. This division, for Appiah, shows a transition beyond the scientific framework. Nevertheless, there is what we call the historical and the sociological views of what a race is or what races are, arising from Appiah's reading of Du Bois's view. This may be the reason why Du Bois prefers the archeological understanding of race. This understanding of race presupposes that there are two distinct discussions of race; the scientific conception and the sociohistorical conception. These conceptions of race, for Appiah, refer to the existing views on racial discourse, where the socio-historical conception represents the view that he wants to discuss about Du Bois in [The Illusions of Race, 1992]. Furthermore, Appiah's attempt to use the scientific conception to reject the existence of race and identity manifested in his later works.

The scientific conception of race refers to biology and anthropology as the views which aids in re-shaping the very nature of race. As Appiah sees it, scientific racism is the use of scientific techniques and hypotheses to support or justify the belief in racism, racial inferiority, or racial superiority, or alternatively, the practice of classifying individuals of different phenotypes into discrete races. In a way, it can be highlighted that scientific racism is pejorative as applied to modern theory of the Bell Curve which investigated racial differences in Intelligence Quotient (IQ), concluding that genetics explained at least part of the IQ differences between races. The socio-historical notion is of the view that no biological or anthropological definition of race is possible.

Moreover, it is pertinent that we discuss the view of racism that is related to -isms. They are 'monogenism', 'polygenism' and 'scepticism'. 'Monogenism' is of the view that all races, no matter how diverse, came from the same source; 'polygenism' is of the view that all races, no matter the distance, much or less diversity, came from different sources, thus races are genuinely diversified; while 'scepticism' about race, in its wholesale version, establishes the habitual doubt cast on the accepted belief about the authenticity of races. Was Du Bois 
influenced by polygenism or monogenism? Can we also say that Appiah was influenced by skepticism about the prospect of monogenism or polygenism? If both social and political theorists are not influenced, what could have influenced their thought-experiments on race and racism? The following analyses of $\mathrm{Du}$ Bois's claim would help us to know whether he is influenced by monogenism or polygenism.

According to Appiah, Du Bois asserts the following grounds and claim:

Premise I: The full, complete Negro message of the whole Negro race has not as yet been given to the world

Premise II: The destiny of the Negro race is not absorption by the white Americans

Premise III: The deeper differences between races are spiritual, psychical, differences - undoubtedly based on physical, but not infinitely transcending them

Premise IV: There is an identity which is strictly the Negro identity, but it is different from the identity of the white and yellow races

Premise V: Race is not scientific, but a socio-historical concept (APPIAH 1992, 30). The reason is because each race has a message just the same way the Negro race has its distinct message which has not yet been given or delivered

\section{Therefore,}

$\mathrm{Du}$ Bois is a racialist. Race exists, not in the way the physical sciences would discuss it, but it is to be clearly defined to the eye of the Historian and Sociologist.

Premise (i) establish the plurality of races. This makes Du Bois a polygenist. Premise (ii) establishes a moral quandary, i.e., a race ought not to absorb another race because their messages have to be delivered to the world (APPIAH 29). In any case, which message do we accept as true, genuine and original amidst the forms of messages that different races have? Premise (iii) reiterates the spirituality and the culturality of a race with its background as different from another race. Premise (iv) establishes the looseness of the concept of identity, i.e., there is no strict form of identity. Identity, in the loose sense, describes each compartmentalized race with its own unique form of identification as different from another compartment of race. The fourth premise helps to reconcile the fundamental problem of identity in the general sense. Premise (v) helps establish the purpose of God for each race, and thus, leading to diverse purposes of God, since there are many races. According to Appiah's reading of Du Bois, the strivings of a race are the stuff of history for that race and that the differences that affect each race distinctively are not to any significant degree biologically determined $(1992,35)$. When races are not to any significant degree biologically determined, it follows that what Du Bois asserts, according to Appiah, is that, races are socio-historically determined.

If we are to consider Appiah's claim that there are no races vis-à-vis Frantz Fanon's racial essentialist discourse in "The Wretched of The Earth," Amilcar Cabral in "National Liberation and Culture," Nelson Mandela's Interventionist 
Ideology during Apartheid, Leopold Senghor's "Negritude: The Basis of African Socialism," and Kwame Nkrumah's reasons for Pan Africanism, as he espoused in his "Consciencism," bothers on the need for Africans to reunite and reignite their potentials, it will be surprising to find out that Appiah may have committed many errors in as many instances with his rejections of race and identity. Furthermore, Stuart Hall's idea that identification (identity of nations and people) are multiple (HALL 1996, 2) cannot walk vis-a-vis Appiah's claim. In this regard, the existence of races and multiple national or cultural identities cannot be ignored. Hall's view, which Cabral, Fanon, Mandela, Senghor, Nyerere, and Nkrumah admit, is that the concept of identity is therefore not an essentialist but a strategic and positional one (HALL, 3). It is possible, in this manner, to say that Hall's view is sound, but this can be interpreted as siding with Hall against Appiah.

In considering the concept of identity, the possibility of it (identity) subjected to the following, (i) un-unified, (ii) fragmented, (iii) fractured, (iv) not singular, (v) multiplied, (vi) intersected, (vii) antagonized, (viii) radical historicization, and (ix) constantly in the process of change and transformation, cannot be deemphasised. Different views by different and opposing discourses, as Hall says, have disturbed the relatively "settled" character of many populations and cultures, above all, in relation to the processes of globalization (HALL, 4). If the claim that there are no races has been problematised, the quest toward racial development which Appiah conscientiously rejects in his later works, then, it is easier to show how dangerous the notions of race and identity could be to the development of humanity or globality. Similar to this danger is Hall's view that the process of 'free' migration has become a global phenomenon of the so-called post colonial world (HALL, 4). In this regard, it has now become a matter of necessary connection between the need to live with people from the side of the world, or the need to have a codified relationship, where Appiah has to theoretically reject the notions of race and identity.

\section{Appiah's View in the Illusions of Race: a Deviation from Du Bois's Claim}

On the one hand, Appiah attempts to reiterate Du Bois's discussion on race. On the other hand, he (Appiah) attempts to posit a new form of discourse on race. His (Appiah's) attempt can be seen in the following: "Du Bois's antithesis is the acceptance of difference along with a claim that each group (Negroes, whites and yellow races) has its part to play, that the white and Negro races are related not as superior to inferior but as complementaries; the Negro message is, with the white one, part of the message of mankind" (APPIAH 1992, 29). This view stipulates the existence of races and the recognition of differences in races. Appiah's reasons why Du Bois's racialist undertone is not appealing rest on the following: 
1. "If there is a claim that a race generally shares a common language, it is plainly inessential" (where inessential mean something that is not absolutely necessary) (APPIAH 1992, 31).

Appiah's derivation faults Du Bois's assertion that a race is a vast family of human beings, always of a common history and traditions (APPIAH 1992, 31). Appiah's avowed rejection of Du Bois's conception of race is because of the problem we may encounter when we have to understand what a family of common history could be. Appiah maintains that Du Bois could have taken it for granted that a race is a matter of birth, and not as a virtue of common descent or choice or biology. This is premised on the resultant view that "biology is democratic: all parents are equal" (APPIAH 31). This suggests that common ancestry is equal to having the large proportion of family trees in the past to coincide. This, for Appiah, is not so.

He (Appiah) explicates in [Cosmopolitanism: Ethics in a World of Strangers, 2006] that there are two views which could help individuals or people in shaping the world: one, we are responsible for other human beings, and two, universal concern and respect for legitimate difference. However, a whole lot of objections to this view can be established. Hence, the discussion of the connection between races or tribes involves the results of multiple disciplines. These include biology, anthropology, sociology, and psychology. Appiah is faulted, on the ground that we are not responsible for other human beings: if we are responsible, it would mean that all human beings emanated from a common family tree situated somewhere. The opinions expressed about the human family in Appiah's later publications of 1996, 2005 and 2006 are relative. Appiah's view do not represent the feelings and agitations of some people, and what these few individuals are going through.

2. Appiah rejects Du Bois's assertion that each race has its distinctive message to deliver to mankind. Appiah's view is that the distinctiveness of each race's message has not in any way undermined the unreality of races. However, Du Bois shares the biological view of race to represent a polygenist methodology of asserting a different origin for all races. It also attempts to assert that a race is not superior to another race. Appiah rejects this polygenist claim about race, where the superiority or inferiority of a race and the distinctiveness of their respective messages does not count. Race, he posits, does not exist. For Appiah, not even the democratic nature of biology could assert the distinctiveness of white race or the yellow race as different or superior to the Negro (black) race.

Appiah further made a comparative discourse, in his work [The Ethics of Identity, 2005] where he defended the 'collective identity'. Collective identity, he posits, is "the collective dimension of our individual identities." Our collective identities, for him, are scripts individuals use in shaping their projects and in telling their life stories, while the society is the big scriptorium" (APPIAH 2005, 21-22). This conclusion implies that a cosmopolitanist or an individual does not 
deny his roots in his own culture, but he is open-minded with regard to other cultures (APPIAH 2005, 41 \& 213). Despite this, he (Appiah) ignored the responses of Africans to various ways of partition and colonial rule between Britain, France, Portugal, Belgium, etc. If Appiah is right, then, the long period of struggles, deprivations, etc, by the European invasion on Africa and Africans does have many implications on the postcolonial life.

Appiah's concession has many shortcomings. One fundamental flaw is this: no impartial student of history can deny that in the case of nearly all recorded relationships, invasions, and forced rulerships, i.e., colonialism, whatever the reasons assigned, the underlying cause of post-colonial conflict has been the existence of racial dislike or aversion in the way in which countries and individuals were subjected to inhumane treatments or to third class treatment. How can nations and individuals treated inhumanely recognize human family or common race? We may help Appiah to say that the treatment which nations in Africa and individuals received during colonialism and recent political, financial, and religious marginalisation should be fanned but the marks people have in their bodies and nations would continually make them to remember the atrocities of the past which they suffered.

3. In Appiah's words, a notion of common history cannot help us to make the fundamental distinction between Slav and Teuton, or between English and Negro. The history of African people is not the same as the history of Teutonic people of Dutch ancestors. This makes Appiah to maintain that:

Just as to recognize two events at different times as part of the history of a single individual, we have to have a criterion of identity for the individual at each of those times, independent of his/her participation in the two events, so, when we recognize two events as belonging to the history of one race, we have to have a criterion of membership of the race at those two times, independently of the participation of the members in the two events. (APPIAH 32)

Precisely, Appiah is stating that "sharing a common group history cannot be a criterion for being members of the same group, for we would have to be able to identify the group in order to identify its history (APPIAH 32). Du Bois's criterion, according to Appiah, is this: "people are members of the same race if they share features in virtue of being descended largely from people of the same region" (APPIAH 33-34). These features, for Appiah, may be physical or cultural.

Appiah's rejection of Du Bois's claim is a derivation of the view that, whatever Africans share, we do not have a common traditional culture, common languages, a common religious or conceptual vocabulary.... We do not even belong to a common race. He (Appiah) jettisoned all attempts by Du Bois to find a universal characteristic defining the black people. His (Appiah's) major premise is that - a biologically rooted conception of race is both dangerous in practice and 
misleading in theory. Furthermore, African unity, African identity, and the idea of Africanness, for Appiah, need securer foundations than race. The two ideas expressed by Appiah above, is a derivative of his earlier view that, "racialism is at the heart of nineteenth-century attempts to develop a science of racial differences" (APPIAH 1992, 13). Racialism would imply the calling for the emergence of black philosophy (which we today call 'African Philosophy'), and this, for Appiah, is a seductive error. The reason is because we do not have an African worldview in a diverse continent of more than 30 nations and numerous languages, tribes and tongues. Black philosophy, for him, would amount to creating something that entail some form of uniquely Negro truth. This position, he says, is in danger of falling into racism. Another implication of racialism is that there would be African philosophers who would see their enterprise as different from their European counterparts. Appiah claims that what we call black philosophy should be seen, first and foremost, as human enterprise. This is because we do not have race.

There are consequential implications of Appiah's analysis of Du Bois with respect to black philosophy. If, as Appiah asserts, that there are no races, it may in turn, mean that there cannot be one universal black philosophy embraced by all blacks which addresses the concerns central to the black experience. Using Senghor's Negritude, there is black humanism: this is central to the black experience. It is a means with which Africans defend their being and experience during and after colonialism. This humanism in Senghor's view "is the African contribution to the civilization of the Universal: the African concern not with a mere collection of individuals but with Africa and the African people conspiring together" (SENGHOR 1998, 440, 443). As a derivative, if there are African philosophers, whatever they write or research about is only a participation in mainstream or Universal philosophy. Furthermore, those who think or agree that they are African philosophers today because there are European (analytic and continental) philosophers or American pragmatists should no longer consider such misleading orientation. Lastly, there is no distinct African thought system as different from European or American thought. Philosophy, he implies, is universalistic in nature and scope.

Appiah's concession cannot be trivialized. The reason for this lies in his attempt to establish a universal racial-family where the divisiveness in race and philosophy should be abandoned. However, there are problems embedded in this framework. One, Appiah seems not to remember that, in the earliest times, it took the form of one race attempting to subjugate and indeed enslave another; but even in modern wars, while questions of frontier, the ambitions of rulers and invaders, or the rivalries of commercial policies, may have provoked the actual crises that we now have today in religion, politics, policies, relationship, tourism, etc., it will be found, in almost every instance, that the pre-existence of social and racial enmity has in reality determined the breach which particular incidents had merely precipitated. Lastly, Appiah is only trying to say that as civilization progresses 
and the Western world fully recognizes its ethical responsibilities, it may be hoped that racial influences should become an ever-diminishing force so that cosmopolitanism or globalization should not thrive in the midst of men. However, there are many views concerning the nature of globalization and what it wants to achieve. Globalization, to some scholars like Idowu Williams, Moses Oke, Julius Nyerere, and Leopold Senghor is a further attempt to subjugate the "Others" or Africans. There reason is predicated on the following: when we get to the global village, whose language are we going to speak or use in communication? When we get to the global village, whose religion/religious beliefs are we going to believe or practice? When we get to the global village, whose policies are we going to prosecute? When we get to the global village, whose orders are we going to follow? These and many more are the questions that requires urgent answers which Appiah has failed to address in his works [The Illusions of Race, 1992], [Color Conscious: The Political Morality of Race, 1996], [The Ethics of Identity, 2005], and [Cosmopolitanism: Ethics in a World of Strangers, 2006].

4. Appiah rejected the biological facets of race mentioned by Du Bois as insufficient to ground the idea of race. His work, [Color Conscious: The Political Morality of Race, 1996] is a good example in establishing the unreality of race. He defended the view that the concept of race is a mistaken American idea and instead, the only race that exists is the human race and that the concept of race ought to be replaced with the notion of racial identity (APPIAH 1996, 32): hence, racial identification is socially significant as it shapes behaviour, actions and life plans. Racial identification as Appiah maintains, is difficult to resist $(1996,82)$.

Here, Appiah misses a point; he failed to place Du Bois within the vitalist tradition, a camp whose conception of race was based on the belief of AfroAmerican superiority, not over all others, but over white Americans. Here, Appiah's reason for rejecting Du Bois's conception of race is based on the implication of his (Du Bois's polygenist and socio-historical) conception of race, where he (Du Bois) calls for the creation of black philosophy as distinct from American or European philosophy. Du Bois's appraisal of the idea of race, for Appiah, is reducible to absurdities and it appears to cloud the common understanding of his (Appiah's) objective that there cannot be races.

Could Appiah have been a monogenist or a polygenist, when it comes to the origin of race? Could he have been neither of the two? Monogenism (or, monogenesis) is the theory of human origins which posits a common descent for all human races, while polygenism is the other side of monogenism. It is admissible that monogenism is an offshoot of Christian faith, and the Christian monogenism played an important role in the development of an AfricanAmerican literature on race, linked to theology rather than science. That is why Du Bois attempts talked about the relevance of Negro race from the message that God has given to them to deliver which is different from the message of the other races - whites and yellow. However, it was Samuel Stanhope Smith, in his 
[Environmentalism and Monogenism] who describes race not from the theological perspective, but asserts that there was a single human origin, but the subsequent migration of groups of humans had subjected them to different environmental conditions (DAIN 2002, 38-40). Thus, polygenism, in its biological form, asserts that different races correspond to different species. This represents an attempt to ignore the supposed specific unity or single species theory of mankind. But according to Augustus Henry Keane, "monogenism was compatible with racial discrimination, via the argument to accept civilization (KEANE 2011, 15).

As a derivative of his reading of $\mathrm{Du}$ Bois, Appiah asserts a racial eliminativist thesis as a result of his avowed skepticism. He posits that there are no races. This makes him a wholesale skeptic (where wholesale skepticism is an outright denial of any knowledge of a thing or entity; i.e., we cannot know. This is premised on the human epistemic constraints). Despite his skepticism, he admits the fact that "the history of Africa is part of the common history of African-American not simply because African-Americans are descended from various peoples who played a part in African history but because African history is the history of people of the same race" (APPIAH 1992, 32). Therefore, Appiah premised the distinctiveness of races on history and not biology, and he pointed out that Du Bois should have noticed this. Based on Du Bois' flaw, Appiah modified his position, in [The Illusion of Races] and his later works. How could Appiah have been a successful racial skeptic if he still admits the distinctiveness of African history and race as different from the history and race of the white and yellow races? He maintains that "the nineteenth-century dispute between monogenesis and polygenesis, between the view that we are descended from one original population and the view that we are descended from several, is over" $(1992,37)$. His (Appiah's) reasons for making this claim is premised on the fact he would not want to be seen or regarded as being monogenic or a polygenic; and two, he would not want to be seen as a racist. Nevertheless, Appiah asserts that "there is no doubt that all human beings (he knowingly did not mention 'race') descend from an original population (probably, as it happens, in Africa), and that from there people radiated out to cover the habitable globe" (APPIAH 1992, 37). This is monogenism at work. This is not a tendency in monogenism because he (Appiah) could not have been indulging in personal preference.

Appiah's skepticism about race rest on the following discourse: "in a sense, trying to classify people into a few races is like trying to classify books in a library: you may use a single property - size, say - but you will get a useless classification, or you may use a more complex of interconnected criteria, and then you will get a good deal of arbitrariness. No one, not even the most compulsive librarian!-thinks that book classifications reflect deep facts about books" (APPIAH 1992, 38). This assertion suggests that race classification can help to settle the kind of race we should value, for the number of decimal system in a scholar's work does not correspond with qualities of utility or interest or literary 
merit. What are the benefit and the price we gain when races are classified? According to Appiah, "the price we pay is that classification becomes a more specialized activity, while the benefit we gain is that we are able to make generalizations of greater power and scope" (APPIAH 1992, 38). This claim is appealing but Appiah fails to recognize that we may not be ready for the change which he wants to bring into racial discourse; meaning that we may not be ready for his explication of/on racial unification. Furthermore, we may not be ready yet to consider all that the common human family signifies or entails. Precisely, we have not tutored our minds to accept to forget the agonies which the past relationship between whites and others brought upon blacks. Just as water cannot be a colorless liquid because color is the cause of demarcation and it helps in identifying limits, asserting that there are no races will be a difficult thing to accept.

Why is there a different position on race (e.g., Appiah's position) as different from his interlocutor? In other words, why is Appiah a racial skeptic when his interlocutor (Du Bois) is a racialist? The reason, as Appiah noted, is that "the classification of people into races would be biologically interesting if both the margins (a limit in condition, capacity, etc., beyond or below which something ceases to exist) and the migrations (movement of people from one place to another) had not left behind a genetic trail. But they have and along that trail are millions of us who can be fitted into no plausible scheme at all" (APPIAH 1992, 38). Surely, Appiah is here referring to his own bi-racialism, but he is not the only bi-racial person. What is the anti-racial tone behind Appiah's assertion? By implication, the following can be suggested: that races exist; that those races fall into plausible and implausible schemes; that these schemes are identical with superiority and inferiority differentials; that the Negroes (black people) are fitted into no plausible scheme because Negroes are genetically inferior and in which he (Du Bois) was a black (of Negro race), while the white race are fitted into plausible schemes; in conclusion, Negroes are fitted into inferior or "no plausible" scheme.

By this interpretation, is it enough simply to gesture at moral concerns while using metaphysics to avoid moral argument given Appiah's view? If what makes Appiah as a racial skeptic is rejected, what implications could this have on African identity? The response to these questions will be highlighted in the following part. As a derivative, Appiah can be seen to have adopted wholesale skepticism in his work [The Illusions of Race]. This leads him to using normative racial eliminativism. Because of what he adopts, Appiah rejects Du Bois' claim that there are races; black (Negroes), white, and yellow, especially in the United States of America. Normative racial eliminativism recommends discarding the concept of race entirely. Appiah's reason, which he derives from Du Bois's explication, in "The Conservation of Races," is that; there is a sort of genetic isolation referring to Negroes, Whites Asians, and Native Americans in the United States. Furthermore, even if there are races, they clearly cannot refer to 
those groupings of people (Negroes, Whites Asians, and Native Americans) presently subsumed under American racial census categories. Because the concept race can only apply to groups not typically deemed races and because the concept of race cannot apply to groups typically deemed races (i.e., African Americans, Whites Asians, and Native Americans), a mismatch occurs between the concept and its typical referent.

In this regard, Du Bois and Appiah's views appear opposing as a result of genetics. However, Joseph Omoregbe's observation cannot be de-emphasized. He (Omoregbe) asserts that "there are such people all over the world; they are to be found among all peoples, in all civilizations and in every part of the globe. It is not only in the Western world that men reflect on the fundamental questions about human life or about the universe. Those who, in any civilization, were particularly struck with "wonder" at the marvels and complexities of the human being or the physical universe, and frequently devoted a lot of time reflecting on the fundamental questions arising from these marvels or complexities, constitute the philosophers of these civilizations" (OMOREGBE 1998, 4). What is central to Omoregbe's claim is the analytic method of analyzing their dispositions on race. However, the important thing is that Appiah cannot sufficiently or conclusively assert that Du Bois's view that there are races is comprehensively faulty or laden with erroneous implications because such claim does not bring the rigor or criticalness of what can be said to constitute the philosophy of race. Using Omoregbe's words that "however, when anyone says that without argumentation and clarification there is strictly no philosophy" $(1998,5)$, it could not have been the case that $\mathrm{Du}$ Bois fails to provide grounds, claim and philosophical clarifications to his argument on the existence of race.

5. Appiah doubted the existence of race because of logical incoherence found in the superior-inferior discourse about races in the United States. Appiah's wholesale skepticism (which makes him to recommend racial eliminativism) is a derivative of the following: "the truth is that there are no races: there is nothing in the world that can do all we ask race to do for us" (APPIAH 1992, 45). This claim presupposes that Appiah's rejection of race is basically from the ontological point of view. However, Appiah's view that there are no races is just being considered at the normative level. Thus, his rejection of race is eliminative and his insistence on the lack of racial identity classifies him as a racial skeptic, not at the Du Bois' socio-historical level.

Central to Appiah's view that there are no races is the direct implication that identity is impossible, as it is explicated in Omoregbe's. In Omoregbe's view, in

( ) "African Philosophy: Yesterday and Today," "it is true that we cannot assert that m an object exists without knowing the object in question" (OMOREGBE 1998, 8). How does this view affect Appiah's claim? The effect is that it is impossible for Appiah not to know the human experiences at different levels before submitting that it does not exist. Appiah must have taken his time to digest the impact of the 
experiences that peoples have in different regions before admitting that the effects which race creates, may not help humanity or Africa, in future endeavours.

On the other hand, Appiah's claim may sound appealing but its lasting impact on Du Bois's claim that "the problem of the twentieth century is the problem of the color-line" is not feasible, as shown in "The Conservation of Races." The problem of race may belong to post-reformation/renaissance but the problem of identity is as old as man. Individuals, groups and nations have sought for identity in the face of different subjugations. Out of 94 top flight coaches in Barclays' premier league, English championship and English Conference, only two of them have black/colored skin. President Barrack Obama became the first black to be voted as the president of the United States but the reality of his black presidency/leadership remains unacceptable to almost, if not all Republicans; Al Qaeda flourishes in the middle-east without any hope of end because of religious, financial and political marginalization from the West/USA; Libya is gone because of the hatred for Gaddafi, Egypt is in deep crises, where the youth are sentenced to death and imprisonments on daily or weekly basis; Syria in still in an unending war; Iraq is demoralized; Afghanistan is not out of the deep waters of the war fought some time ago; Palestine and Israel are unfriendly neighbors; Russia's history which was built around Kiev as the centre-piece is gradually falling; etc. Upon what foundation are we going to premise Appiah's common or distinct human family or his unexisting common race? It is very difficult. The basis of this point is not the presupposition that anyone who agreed with Appiah would be blind to these ongoing problems. If the point suggests that, it would be an unrealistic conclusion from Appiah's view.

Moreover, the circumstances of race and identity may have changed in our time but the outright denial of the existence of race and identity is preposterous. The permission given to people or individuals to air their views or opinions based on the Article 19 of the Universal declaration of Human Rights is very important to the development of racial identity, but the distinction between race and identity shows that racism lives in the mind of men. However, the feeling that certain individuals do not belong is still ever present in men. It is one thing to use race or racism to justify exploitation, while it is another thing to use pseudo-science to justify racial exploitation. Similarly, it is one thing to acknowledge the effects of racism in the way people feel because of the injustice perpetrated in the past to a particular set of people. If race or racism do no longer exist, when will Swahili, Afrikaans, Yoruba, Akan, Bantu, Igbo, Hausa, Tiv, and Twi languages be adopted and be spoken in the global village when we all get there? When will these African languages be placed side-by-side with European languages like Spanish, French, English, Portuguese, German, etc, when globalization achieves its finality or essence? It would be very difficult.

Oddly enough, Appiah spoke out about racism and he analysed it, in [The Illusions of Race] categorizing it into intrinsic and extrinsic kinds (1992, 13-19). Looking at Appiah's explication on racism, his (Appiah's) aim is to end racism 
by promulgating universal race or family. He expressed his position that a key way to end racism would be to discredit the idea of "race." Hence, it is possible that one can disagree with Appiah's methodology with which racism can come to an end, but care must be taken when trying to accuse Appiah for not caring about racism, or about different races or identities.

In a sense, the concept of race and identity may have been developed after men began to encounter other people, fought, and ultimately subdued each other. In another sense, many theorists may have been helped to justify the differences in the treatment of people whom they categorize as belonging to different identity or races. Furthermore, evolutionism may also have had impact on the development of races and identities. Hence, Appiah's view that there are no races cannot sufficiently be justified because there are so many things in the world that can do all we ask race to do for us. A lot of factors may be responsible for our quest to make race to do so many things, and this quest can help further the continuation of race and identity. Simply, race or racism exists and it disconnects people just as religion separated people, politics divided people, and wealth classified people.

\section{A Rejoinder to Appiah's Racial Skepticism}

Appiah's central claim that there are no races may be as a result of the following: he may have been influenced by his background - readings in American pragmatism based on the failings of racial and identity discourses over time (a background that says, since the idea of race and identity has not resolved the post/neo-colonial quest for a distinct African or racial identity, it suffices to defend the idea that race and identity do not exist). This insistence may help the African scholars and activists to abandon the pursuit of racial identity or a distinct race and embrace Appiah's common human family, globality or cosmopolitanism; and two, he may have been influenced by seeing the blacks rising and becoming what was impossible before the signing of the civil right bill in 1964. Thus, since race and identity never brought any good on Africa and its proponents, it will be good to abandon such orientation for a common human family. In what way should Appiah's conclusion on race and identity be faulted?

First and foremost, it is to be faulted based on Tsenay Serequeberhan's opposing or reactionary views that (i) Fanon and Cabral actualizes the historicity of the colonized in the process of anti-colonial struggle, and (ii) we, the colonized/underdeveloped, who feel ourselves to be clumsy in a world of perfect mechanical adjustments, have to reclaim and concretely reinstitute the historicity of our own existence (SEREQUEBERHAN 1998, 17). Thus, it is noteworthy that it is only when one raises a counter-claim which is capable of removing the basis or essence of his position that one can succeed, to a great extent. For instance, Immanuel Kant, in his work "Of the Different Human Races," posits that all humans descend from a common human root, which contained the biological dispositions that can generate the distinct physical traits of race when triggered by 
divergent environmental factors (KANT 2000, 45). This monogenetic account of race and identity by Kant, though different from Appiah's ideas of a global or cosmopolitan human family, but it aids Appiah's claim. It may imply that all humans came from the same racial background, while the difference in races and identities is triggered by environmental factors. Kant's concluding remark differs from Appiah's, but Appiah's thought is that those who live/stay in Africa and are black are of the same race with the Slavs, Teuton and whites. The problem is, Appiah's submission bothers on race and identity as conceived under the American idea of a common human family. It fails to take the following into consideration: the colonized/blacks in the sub-Saharan Africa, the Scandinavians, the Muslims and Christians forging different and opposing identities and the people of the Middle East which constantly act against any marginalization from the West, etc. However, as some other philosophers would believe, polygenesis (the idea that there are many races and identities which nullifies Appiah's conception of a distinct 'human family') remained a viable intellectual strain within race theory. This does not presuppose that polygenesis is a viable scientific theory today. Following the polygenetic view about human race but in a different manner, Tsenay Serequeberhan opines that "the discourse of African philosophy has to be grasped explicitly as a radical hermeneutics of the contemporary African situation. This historically specific situation is that out of which African philosophical hermeneutics spins the thread of its reflexive reflections. Taking its point of departure from the as of yet unfulfilled promise of African "independence," this hermeneutical perspective constitutes the substance of its discourse and critically appropriates as its own the emancipator horizon of the theoretical and political legacy of the African liberation struggle" (SEREQUEBERHAN 1998, 18). Thus, as Serequeberhan further reiterates in support of Du Bois and other scholars who endeavour to admit the relevance and importance of different races and identities, says that "the basic task of philosophy in Africa is explicitly giving the voice to the needful concern of (i) the formerly colonized, the oppressed, that of the underdeveloped, consistently struggles for more justice and equality, and (ii) acknowledging that the efforts at theorizing interpretation and tradition are inscribed interior to the ways and means that tradition itself secretes and utilizes for its own preservation, renewal, and perpetuation" (SEREQUEBERHAN 1998, 16-18). Thus, the claim and counter views on race and identity is unending.

As a derivative of Serequeberhan's analysis, there are many authors who have said that even if "race" is not usually helpful as a biological idea (there are some cases where certain races are susceptible to disease, for example sickle cell anemia, but that is a much diminished role for race compared to what racists has wanted to claim for race), that race is still a factor in identity, and identity based on ethnicity, nation, and religion are still important. It is not fair to Appiah to think or submit that he wants to erase all identity markers of people, which is not what he means by cosmopolitanism. 
Could it have been the case that Appiah's concluding remark eradicates the idea of identity? What are the resultant implications of his (Appiah's) submission on the nature of identity? Why can we not have an identity that is peculiarly African? As a derivative of these questions, Appiah's submission does not fall into the same line of thought with Chinua Achebe. Appiah, while quoting Achebe, in his work "The Myth of an African World," implies the following: there is an Igbo writer (Igbo, as a tribe in Nigeria), a Nigerian and a black. Each specification, to a great extent, asserts an identity. He (Appiah) concludes by quoting that "when you see an African what does it mean to a white man" (APPIAH 1992, 73). This claim, in a way, establishes the differences in identities. Furthermore, Appiah's claim establishes identity as a mental construct. The difference in identities helps to establish the existence of races. Moreover, in his work "Logocentrism and Emotivism: Two Systems in Struggle for Control of Identity," Masolo asserts that "in his famous poem, Aime Cesaire uses the word "Negritude" six different times to conceptualize the dignity, the personhood or humanity of black people" (MASOLO 1994, 1). Senghor's usage of Negritude implies the existence of an identity that is peculiarly African as different from the identity of the 'others' and the non-existent identity of Masolo. Thus, there is race and racial dispositions. Similarly, Chukwudi Eze, in his work "Postcolonial African Philosophy: A Critical Reader," asserts that "the issue of "race" cannot be discounted" (1997, 3). But, if care is not taken, it may be difficult to find out that Masolo is writing an historical overview of identity crisis but submitted that the attainment of identity is impossible.

If we follow Appiah's adoption of (both ontological and normative) the elimination of races because there is a sort of genetic isolation in who qualifies to be recognized as races in the United States, it follows that the claims of different philosophers (like Eze, Achebe, Fanon, Serequeberhan, and Cabral) would amount to nothingness. It is, however, pertinent to say that Masolo defended the impossibility of identity, in the loose sense of the word "identity". He marshals the following argument:

Premise I: As a derivative of the difficulty in having Methodological separatism in Africa and that African philosophy needs a disciplinary unity to exist; and

Premise II: Because, in the quest for re-subjectivizing Africa, we cannot have an identity that is peculiarly African because African philosophy does not have an interdisciplinary approach

\section{Therefore,}

Identity is impossible (1997, 283-285).

How is Masolo's claim possible? The terms 'methodological separatism' and 'disciplinary unity' affirm that problems or issues concerning identity cannot be addressed given the disciplinary separations. Hence, for Africa or African 
philosophy to stand, it needs an interdisciplinary approach. It is this approach that Masolo says is impossible to get; hence, identity is impossible. For example, ecological problems are not just natural science questions, but of course they are not only cultural or social humanities problem areas, either.

To rescue African or black philosophy, Tsenay Serequeberhan quickly reminds us, in "The Critique of Eurocentrism and The Practice of African Philosophy," that there is the need to have progress in human personality (1997, 145). This progress, Serequeberhan says, is to be embedded in the creation of the attitude of self-righteousness for the people of Africa $(1997,145)$. If there is no African race (or, if racism fails to ignite itself because Africans are now involved) and identity is impossible, it would mean, in Serequeberhan's description that, "the "others (Africans)" will receive the Law of Reason from Europe, or Africans (Negroes) will probably receive the law, eventually, from all others. Europe has to give the "law" to all the others (Negroes inclusive)" (SEREQUEBERHAN, 149). The reason for citing Serequeberhan's position is that when race is eliminated and identity that is peculiarly African is no longer in existence, it is implied that the language to be used in communicating effectively at the global village or when the distinct human family is instituted, would not incorporate any of the African languages. It is further implied that different African languages would not represent the effective way of asserting differences in races. These implications would mean that different but not opposing languages will not be the cause of having different cultural identities. Appiah and Masolo may help us in clarifying whether the morphology of Yoruba language corresponds to the morphology of the native French speakers or native English speakers.

It is pertinent to say Appiah's normative racial eliminativism, which recommends discarding the concept of race entirely cannot sufficiently remove the mental ascription of racial discourse in our world and that, both Masolo and Appiah cannot sufficiently remove inferior-orientation ascribed to the "others". In Stuart Hall's words, "people are the producers and consumers of culture at the same time" (HALL 1996, 6). If Hall's claim is feasible, it is difficult to agree with Appiah that there are no races given that his claim and grounds are valid but not sound. The soundness of his grounds fails to correspond to the post-modern reality of the racial inclination/subjugation behind the idea of a global village (where oneness of all races is welcomed and where there is the distinctive peculiarity and oneness of all identities), where the language that is being used is not that of the colonized and the religion to be recognized would never be that of the colonized. If this is the case, we will need to inquire from Appiah and Masolo why race cannot be instituted and why identity is impossible given the challenges facing the very foundation of a common and distinct human family, globalization or cosmopolitanism. Perhaps, they (Appiah and Masolo) may need to have a re-think.

Appiah's re-think of his positions can be premised on the following: (i) philosophy is constituted by diversity (OUTLAW 1998, 29); (ii) the geographical, biological, social, political, and natural-selection factors which influences the 
shared gene pool (as noted by Appiah) cannot condition or characterize race into monogenism; (iii) people of the world are ethnically - hence culturally - diverse and geographically dispersed. To Outlaw, this dispersion was fuelled in Africa by the incursions of Europeans and others (OUTLAW 1998, 29); (iv) Appiah and other race eliminationist need not forget that a cultural reconstruction that fails to incorporate the African perspective, the Arab/Jihadist perspective, religions and cultures as a part of an entire human transformation will fail to stand or be acknowledged (OUTLAW 1998, 33; ASANTE 1980, 5); and (v) the American idea of a common humanity, cosmopolitanism, human family, common gene, or globalization may not be able to hold any sway due to (a) the ability of the five permanent members of UN security council to veto issues, and (ii) people's agitations, killings, referendums for separate nation-states, etc.

\section{Conclusion}

Appiah's view that "there are no races; because there is nothing in the world which we want the race to do for us" $(1992,45)$ has received credence from Stuart Hall that we need to talk about Englishness (DERBYSHIRE 2012, 9). Englishness, in this regard, stands for the universalization and acceptance of the term English, which is the specific or relative. Despite the various attempts made by people to turn globalization or cosmopolitanism into an attempt to bring human races together into a common/distinct human family, we cannot ignore the challenges that lie behind the need to unify the human race into one family. Given Barry Hallen's response to the problems that cosmopolitanism, globalization has on specificity or races, he establish the dynamic approach to philosophizing. This approach conceives of philosophy, according to Hallen, "as a dynamic endeavor whose aim is to encourage the introduction of novel, warrantedly assertible truths about the origins of our beliefs, as well as to reevaluate, revise, or discard old beliefs and to introduce new ideas that might possibly achieve the status of truth" (HALLEN 2002, 27). This approach to philosophy helps in reinventing the idea of race, identity and divergent views arising from cultures, tribes and ethnics. By implication, when novel, warrantedly assertible truths are to be introduced in a globalized or cosmopolitan world, whose language, religion, view, technology, science, politics, sociality, etc, views do we use? Put simply, novel, warrantedly assertible truths would cause chaos when people feel cheated even in the same nuclear family not to talk of different human, cultural, social, political, religious families that exists in our world.

This study submits that Appiah's and Masolo's concessions [The Illusions of Race, 1992], [Color Conscious: The Political Morality of Race, 1996], [The Ethics of Identity, 2005], [Cosmopolitanism: Ethics in a World of Strangers, 2006], "African Philosophy and the Postcolonial: Some Misleading Abstractions about Identity" (1997), fails to walk hand-in-hand with; (i) Oyedola David's explication that "it is only philosophy that is a universal intellectual activity (not race) because it's (philosophy) been pursued by peoples of all cultures" 
(OYEDOLA 2015, 51-74); and (ii) Hallen's view that "the propensity to raise fundamental questions in philosophy (which is even greater than the concept of race) about human experience can be found in peoples belonging to different cultures where the answers given are different/may be different" (HALLEN 2002, 29). Hence, "a number of philosophers of Africa contend that there are elements to African cognition that are sufficiently unique or distinctive to somehow set it apart" (HALLEN, 35). Precisely, in Hallen's view, "each specific human race or continents have their beliefs which have guided their relationship with 'others"" $(2002,29)$.

\section{Relevant Literature}

1. APPIAH, Kwame. [Color Conscious: The Political Morality of Race], 1996. Princeton University Press: Princeton. Paperback.

2. ---. [Cosmopolitanism: Ethics in a World of Strangers], 2006. Princeton University Press:

Princeton. Paperback.

3. - . [The Ethics of Identity], 2005. Princeton University Press: Princeton. Paperback.

4. —. "The Illusions of Race," [In My Father's House: Africa in the Philosophy of Culture], 1992.

Oxford University Press: New York. Paperback.

5. - "The Invention of Africa," [In My Father's House: Africa in the Philosophy of Culture], pp3-27, 1992. Oxford University Press: New York. Paperback.

6. —. "The Myth of an African World," [In My Father's House: Africa in the Philosophy of

Culture], 1992. Oxford University Press: New York. Paperback.

7. ASANTE, M.K. [Afrocentricity: The Theory of Social Change], 1980. Amulefi Publishing Co. Buffalo. Paperback 
Filosofia Theoretica: Journal of African Philosophy, Culture and Religions

8. BIAKOLO, Emevwo. "Categories of Cross-cultural Cognition and the African Condition," [The African Philosophy Reader, COETZEE Pieter and ROUX Abraham Eds.], pp1-14, 1998. Routledge: London. Paperback.

9. CABRAL, Amilcar. "National Liberation and Culture: A Return to the Source," [African Philosophy: An Anthology, EZE Chukwudi Ed.], pp260266, 1998. Blackwell Publishers: Oxford. Paperback.

10.CESAIRE, Aime. "Discourse on Colonialism," [African Philosophy: An Anthology, EZE Chukwudi Ed.], pp222-227, 1998. Blackwell Publishers: Oxford. Paperback.

11. DAIN, B. [A Hideous Monster of the Mind: American Race Theory in the Early Republic], pp38-40, 2002. Google Books: New York. Paperback.

12. DERBYSHIRE, J. "Stuart Hall as a Universalist," [New Statesman], Vol 23, 2012. Paperback.

13. DU BOIS, William. "The Conservation of Races," [African Philosophy: An Anthology,

EZE Chukwudi Ed.], pp269-274, 1998. Blackwell Publishers: Oxford. Paperback.

14.EZE, Chukwudi. [Postcolonial African Philosophy: A Critical Reader], 1997. Blackwell Publishers: Oxford. Paperback.

15. - "Modern Western Philosophy and African Colonialism," [African Philosophy: An Anthology, EZE Chukwudi Ed.], pp213-221, 1998. Blackwell Publishers: Oxford. Paperback.

16. FANON, Frantz. "The Wretched of the Earth," [African Philosophy: An Anthology, EZE Chukwudi Ed.], pp228-233, 1998. Blackwell Publishers: Oxford. Paperback.

17. HALL, Stuart. [Questions of Cultural Identity], HALL, Stuart McPhail and GAY, Paul du (Eds.), 1996. Sage Publications; Routledge: London. Paperback.

18. HALLEN, Barry. [A Short History of African Philosophy], pp1-5, 13-22, 2002. Indiana University Press: Indianapolis. Paperback.

19. HANNAFORD, I. [Race: The History of an Idea in the West], 1996. The John Hopkins University Press: Baltimore. Paperback. 
20. IWERIEBOR, Ehiedu. "The Psychology of Colonialism," [The End of Colonial Rule: Nationalism and Decolonization, FALOLA Toyin Ed.], pp465-482, 2002. Carolina Academic Press: Durham, North Carolina. Paperback.

21. KANT, Immanuel. "Of the Different Human Races," [The Idea of Race, BERNASCONI, R. \& LOTT, T. Eds.], 2000. Hackett Publishing Company: Indianapolis. Paperback.

22. KEANE, A.H. "Ethnology: Fundamental Ethical problems," [The Primary Ethnical Groups], pp13-18, 2011. Google Books: New York. Paperback.

23. MAKINDE, Moses. [African Philosophy: The Demise of a Controversy], pp1-11, 2010. Obafemi Awolowo University Press: Ile-Ife. Paperback.

24. MASOLO, Dismas. "Logocentrism and Emotivism: Two Systems in Struggle for Control of Identity," [African Philosophy in Search of Identity], 1994. Indiana University Press: Bloomington, IN. Paperback.

25. ---. "African Philosophy and the Postcolonial: Some Misleading Abstractions about Identity," [Postcolonial African Philosophy: A Critical Reader, EZE Chukwudi Ed.], pp283-300, 1997. Blackwell Publishers: Cambridge, Massachusetts. Paperback.

26. OMOREGBE, Joseph. "African Philosophy: Yesterday and Today," [African Philosophy: An Anthology, EZE Chukwudi Ed.], pp3-8, 1998. Blackwell Publishers Inc: Malden, Mass. Paperback.

27. OUTLAW, Lucius. "African, African American, Africana Philosophy," [African Philosophy: An Anthology, EZE Chukwudi Ed.], pp23-42, 1998. Blackwell Publishers Inc: Malden Mass. Paperback.

28. OYEDOLA, David. "African Philosophy and the Search for an African Philosopher: The Demise of a Conflictual Discourse," [Filosofia Theoretica: Journal of African Philosophy, Culture and Religions], 4.1 (2015): pp51-74. Paperback.

29. PYKE, K. "What is Internalized Racial Oppression and Why Don't We Study It? Acknowledging Racism's Hidden Injuries," [Journal of Sociological Perspectives], 53.4, 2010. Paperback.

\&30. RISJORD, M. "Methodological Separatism and Reconciliation," [Nursing Knowledge: Science, Practice and Philosophy], 2009. Wiley Blackwell: Oxford. Paperback. 
Filosofia Theoretica: Journal of African Philosophy, Culture and Religions

31. SENGHOR, Leopold. "Negritude and African Socialism," [The African Philosophy Reader, COETZEE Pieter and ROUX Abraham Eds.], pp438448, 1998. Routledge: London.

Paperback.

32. SEREQUEBERHAN, Tsenay. "The Critique of Eurocentrism and the Practice of African Philosophy," [Postcolonial African Philosophy: A Critical Reader, EZE Chukwudi Ed.], 1997. Blackwell Publishers: Cambridge, Mass. Paperback.

33. - "Philosophy and Post-Colonial Africa," [African Philosophy: An Anthology, EZE Chukwudi Ed.], pp8-22, 1998. Blackwell Publishers Inc: Malden, Mass. Paperback.

34. TARA, J. "Whose Culture has Capital? A Critical Race Theory Discussion of Community Cultural Wealth," [Race, Ethnicity and Education], 8.1 (2005): pp69-9. Paperback.

35. TAYLOR, Paul. "Appiah's Uncompleted Argument: W.E.B. Du Bois and the Reality of Race," [Social Theory \& Practice], 26.1 (2000): pp103-128. Paperback.

36. WIREDU, Kwasi. "How Not to Compare African Thought with Western Thought," [African Philosophy: An Anthology, EZE Chukwudi Ed.], pp193199, 1998. Blackwell Publishers: Oxford. Paperback.

37. ZACK, N. [Philosophy of Science and Race], 2002. Routledge: New York. Paperback. 